\title{
GENOTYPE DISTRIBUTION OF THE GB VIRUS C IN CITIZENS OF SÃO PAULO CITY, BRAZIL
}

\author{
Anna S. NISHIYA(1), Gabriela RIBEIRO-DOS-SANTOS(1), Leda BASSIT(1), Roberto FOCACCIA(2), Dalton F. CHAMONE(1) \& Ester C. SABINO(1)
}

\begin{abstract}
SUMMARY
There has been several studies worldwide on phylogenetics and genotype distribution of the GB-virus C / Hepatitis G virus (GBV-C/HGV). However, in their great majority, those investigations were based on some epidemiologically linked group, rather than on a representative sampling of the general population. The present is a continuation of the first study in Brazil with such a population; it addresses the GBV-C/HGV phylogenetics and genotype distribution based on samples identified among more than 1,000 individuals of the city of São Paulo. For this purpose, a 728 bp fragment of the $5^{\prime}$ non-coding region (5'NCR) of the viral genome, from 24 isolates, was sequenced and subjected to phylogenetic analysis. Genotypes 1, $2 \mathrm{a}$ and $2 \mathrm{~b}$ were found at $8.3 \%(2 / 24)$, $50 \%$ (12/24) and 41.7\% (10/24), respectively. In conclusion São Paulo displays a genotype distribution similar to the published data for other States and Regions of Brazil, endorsing the notion that types 1 and 2 would have entered the country with African and European people, respectively, since its earliest formation.
\end{abstract}

KEYWORDS: GB-virus C/Hepatitis G virus (GBV-C/HGV); Genotype distribution; São Paulo City; $5^{\prime}$ non-coding region (5`NCR).

\section{INTRODUCTION}

In the mid nineties two independent groups - looking for a new virus that could be an etiologic agent for the non-A-E hepatitis cases - isolated the Flaviviridae RNA virus, today, collectively referred to as GBV-C/ HGV (GBvirus-C/Hepatitis G Virus) ${ }^{19,39}$. Due to its efficient parenteral transmission, the GBV-C/HGV has been found at high prevalence (14 $45 \%$ ) in different groups worldwide exposed to transfused-blood and hemocomponents and in intravenous drug users ${ }^{10,38}$.

Other illness-related groups have also been found to present high frequency of this virus: 3 to $55 \%$ in hemodialyzed patients ${ }^{20,45}, 15$ to $61 \%$ in subjects who underwent organ transplant ${ }^{31,40}$ and 15 to $21 \%$ in patients with post-transfusional hepatitis ${ }^{14,43}$.

Nonetheless, the GBV-C/HGV has not been confirmed to be the causal agent of the non-A-E hepatitis or of any other disease. Besides, this virus is widely present in healthy subjects, such as blood donors, with variable prevalence: 1 to $3 \%$ in Japan and $\mathrm{USA}^{1,34}$ and more than $10 \%$ in some African and other developing countries ${ }^{4,5}$.

After all, the interest in the GBV-C/HGV has recently been restored - as a benevolent rather than a villain agent - for the allegedly association between its infection and a favorable clinical outcome from HIV-coinfected patients ${ }^{44}$. Yet disputable ${ }^{32}$, this possibility should be further investigated and data on GBV-C/HGV epidemiology, including genotype distribution, should be made available and may be valuable information.
The ubiquitous presence of this virus can be explained by the different ways of transmission it has been associated with: vertical ${ }^{4,50}$, sexual ${ }^{12,32}$ and, possibly, blood-sucking insects ${ }^{30}$.

In Brazil, previous studies reported values for the GBV-C/HGV RNA prevalence in blood donors from 5.5 to $9.7 \%$ in the city of São Paulo ${ }^{3,17,29}$, and in Rio de Janeiro of about $8.2 \%{ }^{15}$. Moreover, our study with a large sampling (1,039 subjects) of the general population of the city of São Paulo showed similar figure: $5.1 \%$ RNA positive samples ${ }^{30}$.

The GBV-C/HGV presents a genomic structure similar to the Hepatitis $\mathrm{C}$ virus (HCV): a single RNA molecule of about $10 \mathrm{~Kb}^{16,19}$. Different genome regions were considered to study genetic variability in various populations throughout the world. In general, the coding regions - NS3 $3^{9,28}$, NS4b, NS5a and NS5 $\mathrm{b}^{13,48}$ have not produced consistent phylogenetic analyses for a GBV-C/HGV classification. Conversely, other studies did lead to genotype classifications by sequencing (i) the noncoding regions $-5^{\prime} \mathrm{NCR}^{2,18,19,22,42}$ (ii) a portion of the coding region for the viral envelope ${ }^{41}$ and (iii) the complete GBV-C/HGV genome ${ }^{24,41}$.

Those studies on strains from various part of the world revealed five different genotypes of the HGV/GBV-C: type 1, predominantly found in Western Africa, 2 in Europe and America, 3 in Asia ${ }^{21,42}$ and, more recently, the subtypes 4 and 5 in Southeast Asia and South of Africa, respectively $23,35,36,41,46,47$.

There are some data on HGV/GBV-C genotype distribution in Brazil. 
NISHIYA, A.S.; RIBEIRO-DOS-SANTOS, G.; BASSIT, L.; FOCACCIA, R.; CHAMONE, D.F. \& SABINO, E.C. - Genotype distribution of the GB virus C in citizens of São Paulo City, Brazil. Rev. Inst. Med. trop. S. Paulo, 45(4): 213-216, 2003.

GALLIAN et al. ${ }^{8}$ have described two genotypes (1 and 2) in a rural population of the Northeast region. Yet in this region, PEREIRA et al. ${ }^{27}$ have found, besides 1 and 2, the genotype 3 in patients co-infected with the hepatitis $\mathrm{C}$ virus (HCV).

In the work of FOCCACIA et al. ${ }^{7}$ more than one thousand subjects were chosen upon specific criteria to allow an epidemiological survey in a representative sampling of the city of São Paulo. Those are invaluable sources for studying phylogenetics and genotype distribution, and no one has so far investigated such a population for these purposes; of those 1,039 samples, 53 turned out to be positive for GBV-C/HGV RNA ${ }^{30}$ and are the subjects of the present work.

\section{MATERIALS AND METHODS}

\section{Serum samples}

The serum specimens were collected between February and May, 1996, in a previous cross-sectional study - conducted to estimate the prevalence of viral hepatitis infection in the city of São Paulo, Brazil ${ }^{7}$. Of those, RNA extraction and RT-PCR (see below) were carried out from 1,039 samples; the 53 positive samples described in our previous work $^{30}$ are the subjects of the present study.

The use of those samples for investigating HGV, among other viruses, was approved by the Committee of Ethical Research of the Institute of Infectology Emilio Ribas (São Paulo, SP); all subjects signed their informed consent.

\section{RNA extraction and GBV-C/HGV reverse transcription and polymerase chain reaction (RT-PCR)}

One hundred $\mu \mathrm{l}$ of serum were added to a $300 \mu$ Trizol $^{\circledR}$ (GIBCOBRL, EUA) solution following the protocol of the INNO-LIPA ${ }^{\mathrm{TM}} \mathrm{HCV}$ II (Innogenetics N.V., Belgium). The RNA-dry precipitate was dissolved in $12 \mu \mathrm{l}$ of Milli-Q/Millipore water treated with dietilpyrocarbonate (DEPC) containing $300 \mathrm{ng}$ of random primer (Random Primer Pharmacia Biotech, Sweden); the solution was kept at $70{ }^{\circ} \mathrm{C}$ for 10 minutes. The cDNA synthesis was carried out by the addition of $200 \mathrm{U}$ of Super Script TM II reverse transcriptase (GIBCO BRL) in a buffer solution with $5 \mathrm{U}$ of ribonuclease inhibitor (GIBCO BRL) and $0.5 \mathrm{mM}$ deoxyribonucleosides trifosfate (dNTPs by Pharmacia or GIBCO BRL) at $42{ }^{\circ} \mathrm{C}$, for 1.5 hour, at a final volume of $20 \mu \mathrm{l}$.

\section{Polymerase chain reaction (PCR)}

A fragment of the 5' non-coding region (5'NCR) was amplified in a reaction mixture containing $20 \mu \mathrm{l}$ of the cDNA solution, $20 \mu \mathrm{l}$ of the primer-mix solution with 40 pmol of FV94-22F FV94-22F - 5' GCAAGCCCCAGAAACCGACGCCTATCTAAGT-3' - and FV94-724F - 5'-GCACAGCCAAACCCGCCTGATACAGT-3' - ${ }^{18}$, 2U Taq-DNAPolymerase (GIBCO BRL), $1.5 \mathrm{mM} \mathrm{MgCl}_{2}(\mathrm{GIBCO} B R L)$ to a final volume of $100 \mu \mathrm{l}$. The reaction was performed in a PTC $200 \mathrm{MJ}$ Research, Peltier Thermal Cycler as follows: an initial step at $95^{\circ} \mathrm{C}$ for 5 minutes, followed by 40 cycles of $94^{\circ} \mathrm{C}$ for 30 seconds, $55^{\circ} \mathrm{C}$ for 30 seconds and $72{ }^{\circ} \mathrm{C}$ for 30 seconds, and a final extension period of 10 minutes at $72{ }^{\circ} \mathrm{C}$. The 728 bp amplified fragment covers nucleotides 39 to 766 of the 5 'NCR in relation to sequence of accession number D87715.
After amplification, $5 \mu$ of the PCR product was used for electrophoresis analysis on a $2 \%$ agarose gel.

PCR control: in each experiment, along with a maximum number of 15 test samples, two water samples and one GBV-C RNA positive sample were included for checking reproducibility of GBV-C RNA extraction, reverse transcription and amplification.

\section{Sequencing and genotyping}

The 728 bp PCR product was purified with the QIAquick kit (QIAGEN, Germany), and directly sequenced in the ABI 310 and 377 sequencer with the ABI PRISM Big Dye Terminator Cycle Sequencing Ready Reaction (PE Applied Biosystems), following their protocol. The sequences were edited using the NAVIGATOR program (Applied Biosystems) and aligned with the sequences of the three main subtypes (Fig. 1) with the CLUSTAL X program ${ }^{11}$. The phylogenetic analysis was carried out with the PHYLIP 3.5 c program $^{6}$. Bootstrap values were determined on 500 replicates of the sequence data with the SEQBOOT program. Phylogenetic reconstructions were generated by the NeighborJoining program ${ }^{33}$, and the distances were calculated by the maximum likelihood with the DNADIST program. The consensus tree was produced by the PAUP program (50\% majority rule).

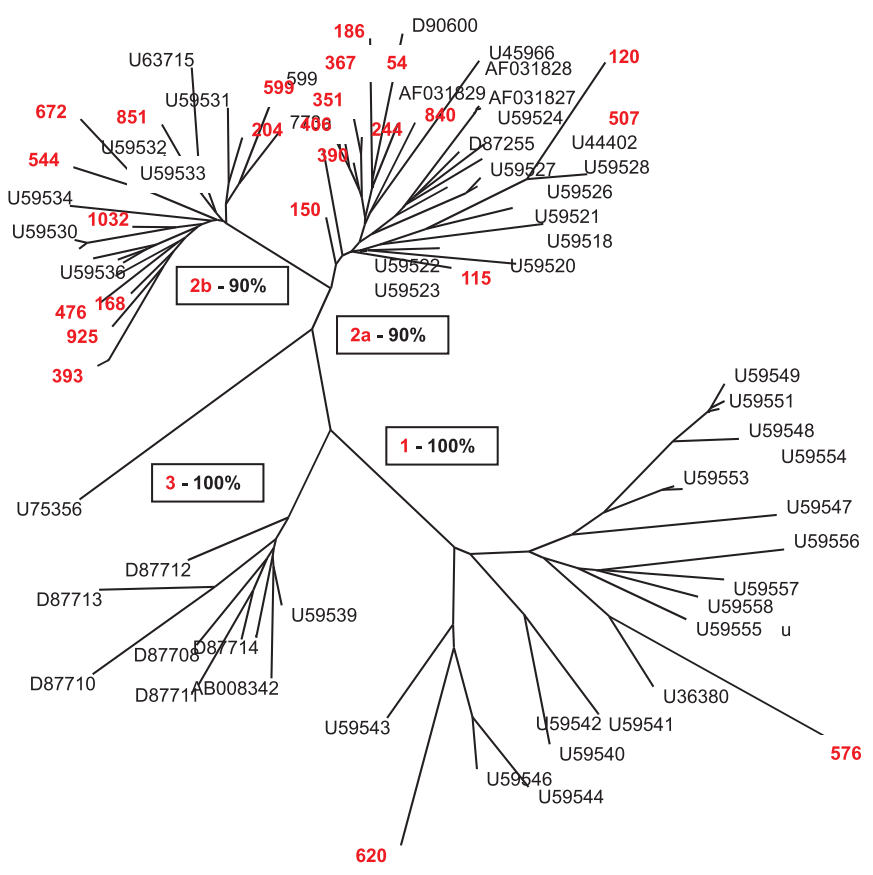

0.1

Fig. 1 - Phylogenetic tree showing the relative evolutionary distance between the GBV-C/ HGV genotypes. Bootstrap analysis values for each genotype are boxed. Red numbers are referred to sequences from this work. The remaining sequences are identified by their Genbank accession number. 


\section{RESULTS}

Of the $53 \mathrm{GBV}-\mathrm{C} / \mathrm{HGV}$ positive samples subjected to PCR amplification, 24 yielded the NCR fragment (728 bp) at concentrations enough for automated sequencing, whereas nineteen produced insufficient material and 10 no detectable yield.

The phylogenetic analysis - carried out with standard strains - has revealed the genotypes $1,2 \mathrm{a}$ and $2 \mathrm{~b}$, at $8.3 \%(2 / 24), 50 \%(12 / 24)$ and $41.7 \%$ (10/24), respectively (Fig. 1).

\section{DISCUSSION}

Sequencing and phylogenetic analysis based on the 5' non-coding region (5'NCR) of nearly half (24/53) of the GBV-C/HGV positive isolates from a large sampling $(1,039)$ of the city of São Paulo disclosed the following genotypes: 1 (8.3\%), $2 \mathrm{a}(50 \%)$ and $2 \mathrm{~b}(41.7 \%)$.

OLIVEIRA et al. ${ }^{25}$ conducted a study with samples from blood donors of the Central Region of Brazil (Goiânia, capital of the State of Goiás), based on the same genome region of the GBV-C/HGV (5'NCR). They reported similar genotype distribution $-2 \mathrm{~b}(58.9 \%), 2 \mathrm{a}(23.5 \%)$ and 1 $(17.6 \%)$ - as determined by restriction fragment length polymorphism ${ }^{25}$.

Studying the 5' untranslated region (5'UTR - another denomination for the non-coding region) of the GBV-C/HGV genome in isolates from a rural population from Bahia (Northeast of Brazil), GALLIAN et al. ${ }^{8}$ have also found type $1(6 / 35,17.1 \%)$ and type $2(29 / 35,82.9 \%)$. Also in the Northeast region, but in patients co-infected with HCV, PEREIRA et al. ${ }^{27}$ have found, besides type $1(1 \mathrm{a}, 5.3 \% ; 1 \mathrm{~b}, 44.7 \%)$ and $2(3.5 \%)$, type 3 $(41.2 \%)$ and mixed infections $(5.3 \%)$ with more than one of these genotypes.

In the neighbor country Argentina, among $21 \mathrm{GBV}-\mathrm{C} / \mathrm{HGV}$ positive samples from human immunodeficiency virus (HIV)-infected intravenous drug users, the same genotypes were found: 1 (4.8\%), 2a (52.4\%) $2 \mathrm{~b}$ $(19 \%)$ and $3(23.8 \%)$; whereas in eleven blood donors they found genotypes $2 \mathrm{a}(45.5 \%), 2 \mathrm{~b}(45.5 \%)$ and $3(9.1 \%)^{26}$.

In conclusion, genotypes 1 and 2 are present in southeastern- and northeastern- Brazilian populations, being type 2 relatively predominant in both cases. However, when studying samples from HCV- and HIVmixed infections, in Brazil and Argentina, genotype 3 appears at high frequencies (see above). The high prevalence of type 3 in more exposed groups might be a consequence of its later entrance in those populations through parenteral and/or sexual route. While types 1 and 2 would have entered the country with African and European people, respectively, since its earliest formation.

\section{RESUMO}

\section{Distribuição dos genótipos do vírus GB-C (HGV) em indivíduos da cidade de São Paulo, Brasil}

Há na literatura vários estudos filogenéticos e de distribuição de genótipos do chamado "Vírus GB-C" ou da "Hepatite G", mais conhecido pela dupla sigla "GBV-C/HGV". Ocorre que, em sua grande maioria, estas pesquisas foram realizadas com amostras de grupos ligados epidemiologicamente e não com indivíduos representativos da população geral. O presente estudo é uma continuação do primeiro trabalho no Brasil feito com este tipo de amostragem. Trata-se de análise filogenética e distribuição genotípica do GBV-C/HGV a partir de amostras isoladas dentre mais de 1.000 indivíduos da cidade de São Paulo. Para tanto, um fragmento de 728 pares de base da região 5' não-codificadora ( $5^{\prime} \mathrm{NCR}$ ) do genoma viral, de 24 amostras, foi sequenciado e submetido à analise filogenética. Foram identificados os genótipos $1,2 \mathrm{a}$ e $2 \mathrm{~b}$ nas respectivas freqüências: $8,3 \%$ (2/24), 50\% (12/24) e 41,7\% (10/24). Concluindo, São Paulo apresenta uma distribuição de genótipos semelhante à publicada para outros estados e regiões do Brasil, endossando a idéia de que os tipos 1 e 2 teriam vindo com os africanos e europeus, respectivamente, e portanto estariam na população do país desde a sua formação.

\section{ACKNOWLEDGEMENTS}

We are grateful to Robson Francisco de Souza for helping with the phylogenetic analysis and to the São Paulo State Agency - FAPESP (Proc.\#96/10078-0), São Paulo, Brasil, for financial support.

\section{REFERENCES}

1. ALTER, H.J.; NAKATSUJI, Y.; MELPOLDER, J. et al. - The incidence of transfusionassociated hepatitis $\mathrm{G}$ virus infection and its relation to liver disease. New Engl. J. Med., 336: 747-754, 1997.

2. AN, P.; WEI, L.; WU, X. et al. - Evolutionary analysis of the 5'-terminal region of hepatitis $\mathrm{G}$ virus isolated from different regions in China. J. gen. Virol., 78: 2477-2482, 1997.

3. BASSIT, L.; KLETER, B.; RIBEIRO-DOS-SANTOS, G. et al. - Hepatitis G virus: prevalence and sequence analysis in blood donors of São Paulo, Brazil. Vox Sang. (Basel), 74: 83-87, 1998.

4. CASTELING, A.; SONG, E.; SIM, J. et al. - GB virus C prevalence in blood donors and high risk groups for parenterally transmitted agents from Gauteng, South Africa. J. med. Virol., 55: 103-108, 1998.

5. DAWSON, G.J.; SCHLAUDER, G.G.; PILOT-MATIAS, T.J. et al. - Prevalence studies of GB virus-C infection using reverse transcriptase- polymerase chain reaction. J. med. Virol., 50: 97-103, 1996.

6. FELSENSTEIN, J. - Phylip: phylogenetic inference package. Seattle, University of Washington, 1993. (version 3.5c)

7. FOCACCIA, R.; DA CONCEIÇÃO, O.J.; SETTE Jr., H. et al. - Estimated prevalence of viral hepatitis in the general population of the municipality of São Paulo, measured by a serologic survey of a stratified, randomized and residence-based population. Braz. J. infect. Dis., 2: 269-284, 1998.

8. GALLIAN, P.; RODRIGUES, V.; CANTALOUBE, J.F. et al. - High prevalence of GB$\mathrm{C} /$ hepatitis $\mathrm{G}$ virus in a Brazilian population with helminth infection. J. med. Virol., 56: $310-315,1998$.

9. GIMENEZ-BARCONS, M.; IBANEZ, A.; TAJAHUERCE, A. et al. - Genetic evolution of hepatitis $G$ virus in chronically infected individual patients. J. gen. Virol., 79: 2623-2629, 1998

10. GUTIERREZ, R.A.; DAWSON, G.J.; KNIGGE, M.F. et al. - Seroprevalence of GB virus C and persistence of RNA and antibody. J. med. Virol., 53: 167-173, 1997.

11. HIGGINS, D.G. \& SHARP, P.M. - CLUSTAL: a package for performing multiple sequence alignment on a microcomputer. Gene, 73: 237-244, 1988.

12. IBANEZ, A.; GIMENEZ-BARCONS, M.; TAJAHUERCE, A. et al. - Prevalence and genotypes of $\mathrm{GB}$ virus $\mathrm{C} /$ hepatitis $\mathrm{G}$ virus (GBV-C/HGV) and hepatitis $\mathrm{C}$ virus among patients infected with human immunodeficiency virus: evidence of GBV-C/HGV sexual transmission. J. med. Virol., 55: 293-299, 1998. 
NISHIYA, A.S.; RIBEIRO-DOS-SANTOS, G.; BASSIT, L.; FOCACCIA, R.; CHAMONE, D.F. \& SABINO, E.C. - Genotype distribution of the GB virus C in citizens of São Paulo City, Brazil. Rev. Inst. Med. trop. S. Paulo, 45(4): 213-216, 2003.

13. KHUDYAKOV, Y.E.; CONG, M.E.; BONAFONTE, M.T. et al. - Sequence variation within a nonstructural region of the hepatitis G virus genome. J. Virol., 71: 6875-6880, 1997.

14. KOMATSU, H.; FUJISAWA, T.; INUI, A. et al. - GBV-C/HGV infection in children with chronic hepatitis C. J. med. Virol., 59: 154-159, 1999.

15. LAMPE, E.; DE OLIVEIRA, J.M.; PEREIRA, J.L. et al. - Hepatitis G virus (GBV-C) infection among Brazilian patients with chronic liver disease and blood donors. Clin. diagn. Virol., 9: 1-7, 1998.

16. LEARY, T.P.; MUERHOFF, A.S.; SIMONS, J.N. et al. - Sequence and genomic organization of GBV-C: a novel member of the flaviviridae associated with human non-A-E hepatitis. J. med. Virol., 48: 60-67, 1996.

17. LEVI, J.E.; CONTRI, D.G.; LIMA, L.P. et al. - High prevalence of GB virus C/hepatitis G virus RNA among Brazilian blood donors. Rev. Inst. Med. trop. S. Paulo, 45: 75 $78,2003$.

18. LINNEN, J.; FUNG, K.; FRY, K.E. et al. - Sequence variation and phylogenetic analysis of the 5' terminus of hepatitis G virus. J. viral Hepatitis, 4: 293-302, 1997.

19. LINNEN, J.; WAGES Jr., J.; ZHANG-KECK, Z.Y. et al. - Molecular cloning and disease association of hepatitis G virus: a transfusion-transmissible agent. Science, 271: 505508, 1996.

20. MASUKO, K.; MITSUI, T.; IWANO, K. et al. - Infection with hepatitis GB virus C in patients on maintenance hemodialysis. New Engl. J. Med., 334: 1485-1490, 1996.

21. MUERHOFF, A.S.; SIMONS, J.N.; LEARY, T.P. et al. - Sequence heterogeneity within the 5'-terminal region of the hepatitis GB virus $\mathrm{C}$ genome and evidence for genotypes. J. Hepat., 25: 379-384, 1996.

22. MUERHOFF, A.S.; SMITH, D.B.; LEARY, T.P. et al. - Identification of GB virus C variants by phylogenetic analysis of 5 '- untranslated and coding region sequences. $\mathbf{J}$. Virol., 71: 6501-6508, 1997.

23. NAITO, H.; WIN, K.M. \& ABE, K. - Identification of a novel genotype of hepatitis G virus in Southeast Asia. J. clin. Microbiol., 37: 1217-1220, 1999.

24. OKAMOTO, H.; NAKAO, H.; INOUE, T. et al. - The entire nucleotide sequences of two GB virus $\mathrm{C} /$ hepatitis $\mathrm{G}$ virus isolates of distinct genotypes from Japan. J. gen. Virol., 78: 737-745, 1997

25. OLIVEIRA, L.A.; MARTINS, R.M.B.; CARNEIRO, M.A.S. et al. - Prevalence and genotypes of GB virus C / hepatitis G virus among blood donors in central Brazil. Mem. Inst. Oswaldo Cruz, 97: 953-957, 2002.

26. OUBINA, J.R.; MATHET, V.; FELD, M. et al. - Genetic diversity of GBV-C/HGV strains among HIV infected-IVDU and blood donors from Buenos Aires, Argentina. Virus Res., 65: 121-129, 1999.

27. PEREIRA, L.M.; SPINELLI, V.; XIMENES, R.A. et al. - Chronic hepatitis C infection: influence of the viral load, genotypes, and GBV-C/HGV coinfection on the severity of the disease in a Brazilian population. J. med. Virol., 67: 27-32, 2002.

28. PICKERING, J.M.; THOMAS, H.C. \& KARAYIANNIS, P. - Predicted secondary structure of the hepatitis G virus and GB virus-A 5'untranslated regions consistent with an internal ribosome entry site. J. viral Hepatitis, 4: 175-184, 1997.

29. PINHO, J.R.; ZANOTTO, P.M.; FERREIRA, J.L. et al. - High prevalence of GB virus C in Brazil and molecular evidence for intrafamilial transmission. J. clin. Microbiol., 37: 1634-1637, 1999.

30. RIBEIRO-DOS-SANTOS, G.; NISHIYA, A.S.; NASCIMENTO, C.M. et al. - Prevalence of GB virus C (hepatitis G virus) and risk factors for infection in São Paulo, Brazil. Europ. J. clin. Microbiol. infect. Dis., 21: 438-443, 2002.

31. ROSS, R.S.; VIAZOV, S.; SCHMITT, U. et al. - Distinct prevalence of antibodies to the $\mathrm{E} 2$ protein of GB virus C/hepatitis G virus in different parts of the world. J. med. Virol., 54: 103-106, 1998.
32. SABIN, C.A.; DEVEREUX, H.; KINSON, Z. et al. - Effect of coinfection with hepatitis $\mathrm{G}$ virus on HIV disease progression in hemophilic men. J. Acquir. Immune Defic. Syndr., 19: 546-548, 1998.

33. SAITOU, N. \& NEI, M. - The neighbor-joining method: a new method for reconstructing phylogenetic trees. Molec. Biol. Evol., 4: 406-425, 1987.

34. SAIZ, J.C.; AMPURDANES, S.; OLMEDO, E. et al. - Hepatitis G virus infection in chronic hepatitis $\mathrm{C}$ : frequency, features and response to interferon therapy. J. Hepat., 26: 787-793, 1997.

35. SATHAR, M.A. \& YORK, D.F. - Group 5: GBV-C/HGV isolates from South Africa. J. med. Virol., 65: 121-122, 2001

36. SATHAR, M.A.; SONI, P.N.; PEGORARO, R. et al. - A new variant of GB virus C/ hepatitis G virus (GBV-C/HGV) from South Africa. Virus Res., 64: 151-160, 1999.

37. SCALLAN, M.F.; CLUTTERBUCK, D.; JARVIS, L.M.; SCOTT, G.R. \& SIMMONDS, P. - Sexual transmission of GB virus C/hepatitis G virus. J. med. Virol., 55: 203 208, 1998 .

38. SHRESTHA, S.M.; SHRESTHA, S.; TSUDA, F. et al. - Infection with GB virus C and hepatitis $\mathrm{C}$ virus in drug addicts, patients on maintenance hemodialysis, or with chronic liver disease in Nepal. J. med. Virol., 53: 157-161, 1997.

39. SIMONS, J.N.; LEARY, T.P.; DAWSON, G.J. et al. - Isolation of novel virus-like sequences associated with human hepatitis. Nature Med., 1: 564-569, 1995.

40. SKIDMORE, S.J. \& COLLINGHAM, K.E. - Prevalence of GB virus-C/hepatitis G virus infection in an antenatal population. J. med. Virol., 57: 235-237, 1999.

41. SMITH, D.B.; BASARAS, M.; FROST, S. et al. - Phylogenetic analysis of GBV-C/ hepatitis G virus. J. gen. Virol., 81: 769-780, 2000.

42. SMITH, D.B.; CUCEANU, N.; DAVIDSON, F. et al. - Discrimination of hepatitis G virus/GBV-C geographical variants by analysis of the 5' non-coding region. J. gen. Virol.,78: 1533-1542, 1997.

43. SUGAI, Y.; NAKAYAMA, H.; FUKUDA, M. et al. - Infection with GB virus C in patients with chronic liver disease. J. med. Virol., 51: 175-181, 1997.

44. TILLMANN, H.L.; HEIKEN, H.; KNAPIK-BOTOR, A. et al. - Infection with GB virus $\mathrm{C}$ and reduced mortality among HIV-infected patients. New Engl. J. Med., 345: 715-724, 2001

45. TSUDA, F.; HADIWANDOWO, S.; SAWADA, N. et al. - Infection with GB virus C (GBV-C) in patients with chronic liver disease or on maintenance hemodialysis in Indonesia. J. med. Virol., 49: 248-252, 1996.

46. TUCKER, T.J. \& SMUTS, H.E. - GBV-C/HGV genotypes: proposed nomenclature for genotypes 1-5. J. med.Virol., 62: 82-83, 2000.

47. TUCKER, T.J.; SMUTS, H.; EICKHAUS, P.; ROBSON, S.C. \& KIRSCH, R.E. Molecular characterization of the 5' non-coding region of South African GBV-C/ HGV isolates: major deletion and evidence for a fourth genotype. J. med. Virol., 59: 52-59, 1999.

48. VIAZOV, S.; RIFFELMANN, M.; KHOUDYAKOV, Y. et al. - Genetic heterogeneity of hepatitis $\mathrm{G}$ virus isolates from different parts of the world. J. gen. Virol., 78: 577 $581,1997$.

49. VIAZOV, S.; RIFFELMANN, M.; SARR, S. et al. - Transmission of GBV-C/HGV from drug-addicted mothers to their babies. J. Hepat., 27: 85-90, 1997.

50. ZANETTI, A.R.; TANZI, E.; ROMANO, L. et al. - Multicenter trial on mother-to-infant transmission of GBV-C virus. The Lombardy Study Group on Vertical/Perinatal Hepatitis Viruses Transmission. J. med. Virol., 54: 107-112, 1998.

Received: 07 February 2003

Accepted: 24 July 2003 